\title{
Research on the Influence of Social Network on the Growth of Middle and Upper-level Female Management Talents
}

\author{
He Huang \\ Foshan University, Guangdong Foshan, 528000, China
}

Keywords: social network; pleasantness; female managers; growth

\begin{abstract}
The research proves that social network has positive or negative influence on the career success of enterprise managers, but it needs to study whether it has any influence on female high-level management talents in enterprises. This research mainly studies the influence of social network on the growth of female middle and senior management talents in enterprises by means of data statistics such as regression analysis and questionnaire survey. It is concluded that network heterogeneity has a positive impact on the growth of middle- and high-level managers of female enterprises. The network scale and relationship intensity have some positive effects. The network density has a negative impact on the growth of middle- and high-level managers of female enterprises. At the same time, amenity plays a part in regulating the influence of social networks on the growth of middle- and high-level managers of female enterprises.
\end{abstract}

\section{Introduction}

The National Medium- and Long-Term Talent Development Plan (2010-2020) highlights the leading role of high-level talents and also emphasizes the importance of middle- and high-level female managers. Studies have shown that successful managers spend $70 \%$ more time on network activities than their competitors; they spend $10 \%$ more time on daily communication activities. For female managers, the impact of social networks on their growth and talent is also very important. At present, Chinese and foreign scholars rarely take the middle and senior managers of corporate women as research objects. As a personality trait, "Pleasantness" has no relevant research on the role played by social networks and the growth of women's middle and senior management talents. This study is based on this theme ${ }^{[1]}$.

\section{Literature review}

\subsection{Social network}

The social network referred to in this paper refers to a network composed of others who have actual contact and interaction with the senior managers in the growth process of the enterprise and who can have an important influence on their career success. Social networks can be measured by four indicators: network size, network density, network heterogeneity, and relationship strength ${ }^{[2]}$. 


\subsection{The impact of social networks on the growth of management talents}

Studies have shown that the network of interpersonal relationships within and outside the organization is an important predictor of management talent growth and success. The more informal networks an individual has in an organization, the more information and resources they receive, and the greater the likelihood of promotion ${ }^{[3]}$.

\subsection{The growth and measurement of middle and high-level female management talents in enterprises}

The research experience shows that it is feasible to measure the growth of high-level management talents of female enterprises by using the combination of subjective and objective indicators of professional success. From the perspective of professional success, it can be subdivided into objective criteria and subjective criteria: objective criteria mainly include social status, prestige and influence, salary level and position promotion, market internal competitiveness and market external competitiveness; Subjective criteria mainly include job satisfaction, career satisfaction, career participation, career success perception, promotion opportunity perception, and life satisfaction ${ }^{[4]}$.

\subsection{Pleasantness}

Pleasantness, as a personality trait, belongs to one of the five factors of personality in the Big Five personality theory. Pleasantness is used to examine an individual's attitude towards others around him. In general, high amenity is generous, helpful, and understanding, and is willing to give up their own interests in order to fulfill others ${ }^{[5]}$.

\section{Theoretical model and research hypothesis}

\subsection{Theoretical model}

The literature proves that social networks do have an important impact on the growth of management talents in middle and high-level women. However, further empirical tests are needed, so the following theoretical model is established, as shown in Figure 1.

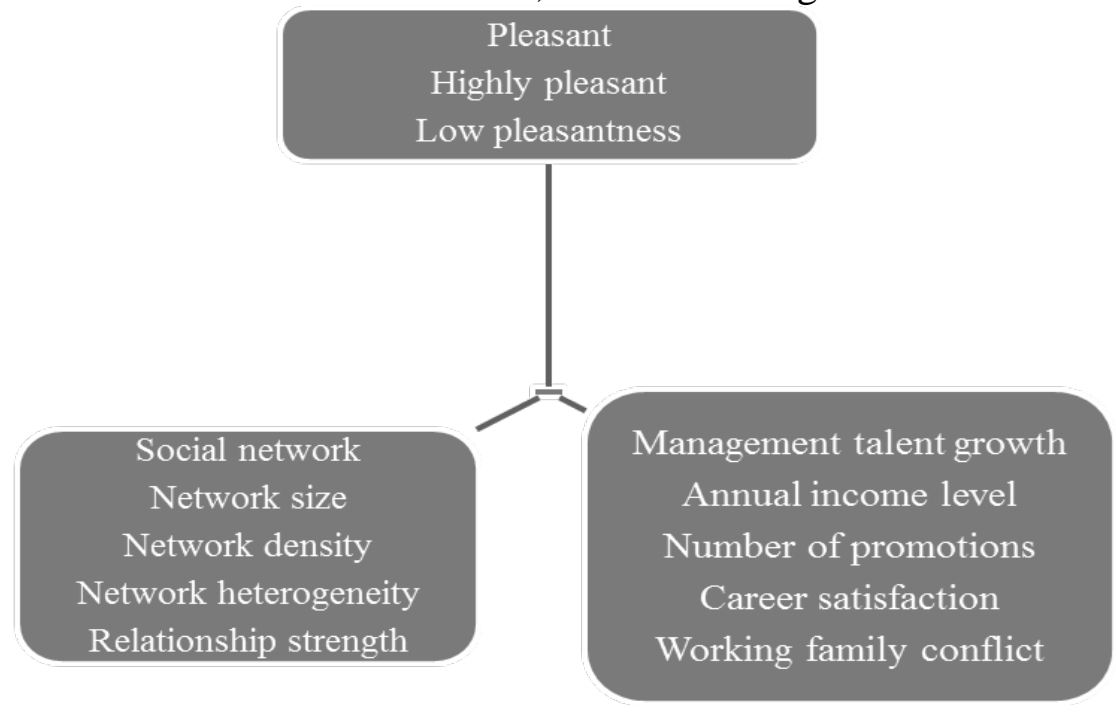

Figure 1 Theoretical model 


\subsection{Research hypothesis}

1) Social network: network scale and growth of middle- and high-level female management talents in the enterprise, network density and growth of middle- and high-level female management talents in the enterprise, network heterogeneity and growth of middle- and high-level female management talents, relationship strength and growth of middle- and high-level female management talents

This article assumes the following assumptions:

H1: Network size, network density, network heterogeneity, and relationship strength have a positive impact on the growth of mid- and high-level female management talents. That is, the network scale, network density, network heterogeneity and the greater the strength of the relationship, the more favorable to its growth; The more unfavorable to growth.

H1a: Network size, network density, network heterogeneity, and greater relationship strength, the higher the annual income level; On the contrary, the lower the annual income level.

H1b: The larger the network size, network density, network heterogeneity and relationship strength, the more promotion times; On the contrary, the fewer the promotion.

H1c: The greater the network size, network density, network heterogeneity and relationship strength, the higher the job satisfaction; On the contrary, the lower the job satisfaction.

H1d: Network size, network density, network heterogeneity, and greater relationship strength, the smaller the work-family conflict; On the contrary, the greater the work-family conflict.

2) The regulation of pleasantness

This paper proposes the following assumptions:

H2: Pleasantness regulates the relationship between social networks and the growth of middleand high-level female management talents in enterprises. That is, high amenity is relative to low amenity. The influence of social networks on the growth of middle- and high-level female management talents is increasing. In terms of low a pleasantness and high amenity, the influence of social networks on the growth of middle- and high-level female management talents is weakening.

\section{Sample and variable measurement}

\subsection{Sample size and acquisition process}

The sample of this paper is the middle and senior managers of enterprise women. The questionnaires are distributed and recycled in both paper and electronic versions. In the end, 243 paper-based questionnaires were collected, 237 valid questionnaires, and 57 valid questionnaires were collected through questionnaires. A total of 294 valid questionnaires were collected, with an effective rate of $98 \%$.

\subsection{Variable metric}

The contents of the questionnaire include: social network, measurement of the growth of middleand high-level female management talents, and measurement of amenit.

\subsection{Data processing method}

This study used SPSS16.0 statistical software analysis, mainly using descriptive statistical analysis, effect, reliability analysis, correlation analysis and regression analysis. 


\subsection{Result analysis}

Taking the social network as the independent variable, the middle and high-level female management talents as the dependent variable, and the pleasantness as the adjustment variable, the regression analysis was carried out. Because the four dimensions of the growth of high-level management talents of female enterprises (annual income level, promotion number, occupational satisfaction, work-family conflict) cannot be combined, we have respectively carried out regression analysis results between pleasantness and these four dimensions. As shown in Table 1.

Table 1 Regression Analysis of Pleasantness and the Growth of Middle- and High-level Female Management Talents

\begin{tabular}{|c|c|c|c|c|c|c|c|}
\hline $\begin{array}{c}\text { Independent } \\
\text { variable }\end{array}$ & $\begin{array}{c}\text { Dependent } \\
\text { variable } \\
\text { annual income } \\
\text { level }\end{array}$ & .283 & .286 & 6.701 & .000 & 0.219 & 44.903 \\
\hline & $\begin{array}{c}\text { number of } \\
\text { promotions }\end{array}$ & .184 & .185 & 5.739 & .000 & 0.162 & 32.931 \\
\hline & career satisfaction & .287 & .285 & 6.699 & .000 & 0.218 & 44.877 \\
\hline & $\begin{array}{c}\text { Working family } \\
\text { conflict }\end{array}$ & -.185 & -.187 & -5.816 & .000 & 0.172 & 33.825 \\
\hline
\end{tabular}

\section{Conclusions}

The study used regression analysis and other statistical methods to verify the relationship between the social network, the amenity of the middle and senior managers of the enterprise and the three variables of the middle and high-level female management talent growth. The following research results are obtained: (1) In the context of China, the middle- and upper-level managers of corporate women still have credibility and effectiveness, and have applicability to middle- and high-level managers of corporate women. (2) Through the data analysis methods such as regression analysis, the relationship between social network and the growth of middle- and high-level female management talents in the enterprise, and the partial adjustment effect of pleasantness between the two variables are tested.

\section{Acknowledgement}

The research in this paper was supported by Guangdong Provincial Education Department Project: Research on the Relationship between Female Managers and Enterprise Growth under the social network (2015WQNCX147).

\section{References}

[1] Liu Jinyan. Research on the mechanism of social network on the growth of high-level management talents of female enterprises [D]. Jilin University, 2012.

[2] Xu Zesheng. Research on the relationship between network centrality and knowledge sharing of middle and senior management personnel [D]. South China University of Technology, 2013.

[3] Meng Yang. Research on the relationship between managerial relationship psychological contract and organizational performance under multi-network embedding[D]. Qingdao University of Science and Technology, 2017.

[4] ZXu Juan. An Empirical Study of the Influence of Female Executives on Corporate Performance [D]. Nanjing Normal University, 2014.

[5] Ma Dongling. Research on the Growth Law of Female Enterprise Executives--Based on the Data Analysis of the Third Phase of Chinese Women's Social Status Survey[C]// International Symposium on Chinese Women's Human Resource Development and Utilization. 2013. 